\title{
IMPLEMENTATION OF HACCP IN THE MEXICAN POULTRY PROCESSING INDUSTRY
}

\author{
Ema Maldonado-Siman ${ }^{1, *}$, Pedro Arturo Martínez-Hernández ${ }^{1}$, Agustín \\ Ruíz-Flores ${ }^{1}$, José G. García-Muñiz ${ }^{1}$, José A. Cadena-Meneses ${ }^{1}$ \\ ${ }^{1}$ Posgrado en Producción Animal. Universidad Autónoma Chapingo. Km. 38.5 Carretera \\ México-Texcoco. 56230. Texcoco, Edo. de México. \\ * Corresponding author, Address: Posgrado en Producción Animal, Universidad Autónoma \\ Chapingo. Km. 38.5 Carretera México-Texcoco. 56230. Texcoco, Edo. de México, Tel: \\ +52-(595)95216-21, Fax:+52-(595)95216-89, Email: mamaldonado@correo.chapingo.mx
}

Abstract: Hazard Analysis and Critical Control Point (HACCP) is a safety and quality management tool used as major issue in international and domestic trade in food industry. However, detailed information on costs and benefits of HACCP implementation is needed to provide appropriate advice to food processing plants. This paper reports on the perceptions of costs and benefits by the Mexican poultry processing plants and sale destinations. The results suggest that the major costs of implementing and operating HACCP within poultry processing plants are record keeping and external technical advice. The main benefit indicated by the majority of processing plants is a reduction in microbial counts. Over $39 \%$ of poultry production is sent to nation-wide chains of supermarkets, and less than $13 \%$ is sent to international markets. It was concluded that the adoption of HACCP by the Mexican poultry processing sector is based on the concern to increase and keep the domestic market, rather than to compete in the international market.

Keywords: HACCP implementation, Mexican Poultry Industry, costs and benefits.

\section{INTRODUCTION}

Meat and poultry products are sensitive to biological contamination and after then, they provide an excellent environment for growth of bacteria. This kind of contamination may result in foodborne illness (Northcutt and

Please use the following format when citing this chapter:

Maldonado-Siman, E., Martínez-Hernández, P.A., Ruíz-Flores, A., García-Muñiz, J.G. and CadenaMeneses, J.A., 2009, in IFIP International Federation for Information Processing, Volume 295, Computer and Computing Technologies in Agriculture II, Volume 3, eds. D. Li, Z. Chunjiang, (Boston: Springer), pp. 1757-1767. 
Scott, 2003). For that reason, food sector trends focus on food safety regulations. Besides, consumers demand safer food because of their better knowledge and handling of food, affluence and longevity (Unnevehr and Jensen, 1998). They also recognize the potential seriousness of foodborne diseases and the problem involved because of lack of information on safe handling and storage of food products (Unnevehr and Jensen, 1998).

As a consequence, food safety becomes one of the priorities of countries as foodborne diseases are a large public health problem (Engler et al., 2005). Moreover, stricter regulations apply for importing and exporting countries involved on world trade (Dohlman, 2003). Exporting developing countries center on the effect of rigorous food safety standards set in import markets of developed countries and their ability to export to these markets. In contrast, principal issue for importing countries is to meet the demand of consumers on food safety. As a result, a new approach to ensure safety of the food is the mandatory use of the Hazard Analysis Critical Control Point (HACCP) system in food industries (Unnevehr and Jensen, 1998).

A complex interrelation among governments, industry and consumers is required to implement HACCP (Salay and Caswell, 1998). Private and public incentives are implicated in food industry's response to regulations in order to improve food safety. It involves a complex regulatory analysis of costs (Unnevehr and Jensen, 2001). Segerson (1999) mentioned that enterprises may adopt HACCP system to satisfy incentives or in anticipation of more rigorous regulation. Nevertheless, cost and time for full HACCP implementation vary widely in food processing enterprises (Martin and Anderson, 1999). On the other side, studies reported that many enterprises may not have reliable costs and benefits estimation of HACCP implementation beforehand and it could be major restrain for planning HACCP (Calatore and Caswell, 1999). Thus, essential information is necessary to evaluate concretely the magnitude of costs in each type of plant prior to adoption (Maldonado et al., 2005). The aim of this paper is to explore the process of HACCP implementation in the Mexican poultry meat sector, to identify product destinations, and to offer information about the costs and benefits of HACCP implementation and major problems involved into the process.

\section{MATERIALS AND METHODS}

A total of 32 plants listed under the poultry meat sector were sent a questionnaire (Henson et al., 1999) during the period 2000-2001 and revisited in 2003. A total of 21 questionnaires were fully completed, 9.5\% 
were returned by mail and $90.5 \%$ by direct interview. These enterprises form part of Federal Inspection Type (TIF) meat processing plants of the Ministry of Agriculture, Livestock, Rural Development, Fisheries and Food (SAGARPA) which is in charge of direct control of food quality on meat and poultry processing plants in Mexico.

In addition, the survey included a series of questions intended to collect information about firm characteristics, customers and products and the status of implementation of HACCP and asked about aspects related to costs, benefits and difficulties of implementation. The respondents ranked difficulty factors in order of importance according to their own conditions, using a seven-point Likert scale ranging from "very important" (1) to "very unimportant" (7); and a set-up cost and benefits in HACCP implementation and operation (Deodhar, 2003), identifying "major" or "minor" cost and benefits by the enterprises. Data was analyzed using SAS (SAS, 2001).

\section{RESULTS AND DISCUSSION}

Fully answered questionnaires represented $65.6 \%$ of poultry meat TIF plants. Table 1 shows basic sample characteristics of those enterprises. Plants carry out seven types of poultry processing. Slaughter and packing activities (38.1\%) registered the major production level, following by cold cuts $(19.0 \%)$. The rest five processes $(42.9 \%)$ were recorded by nine plants.

One third of the sampled plants had between 51 and 200 employees, and other third of respondents had more than 401 employees on plants. Fortythree percent of the firms have been in operation no more than five years, whilst less than $10.0 \%$ were operating on market for more than 21 years. On the other side, only $33.3 \%$ of the enterprises reported having more than one plant. Three of them had two plants operating, and four of them operated between three to nine plants. In addition, $71.4 \%$ of the products of the enterprises were branded under their own company's brand name, $47.6 \%$ under a retailer's brand name and only $19.0 \%$ under another manufacturer's brand name.

Further details of the seven destinations for the production of the 21 TIF poultry meat enterprises surveyed and main marketing destination are reported in Fig. 1. Fifteen firms were involved in having commercial contracts with supermarkets and send them $39.6 \%$ of their production. The quality control systems for this segment of sale chains frequently are a primary target, so it moves faster in the direction of certification and traceability requirements (Henson and Caswell, 1999). 

Agustín Ruíz-Flores , José G. García-Muñiz , José A. CadenaMeneses

\begin{tabular}{|c|c|c|c|}
\hline & Frequency & Percentage & Cumulativepercentage \\
\hline \multicolumn{4}{|l|}{ Type of processes } \\
\hline Cold cuts & 4 & 19.0 & 19.0 \\
\hline De-boning & 2 & 9.5 & 28.6 \\
\hline Hamburgers and nuggets & 2 & 9.5 & 38.1 \\
\hline Packing & 1 & 4.8 & 42.9 \\
\hline Pasteurized liquid and dehydrated eggs & 2 & 9.5 & 52.3 \\
\hline Prepared meals & 2 & 9.5 & 61.9 \\
\hline Slaughter and packing & 8 & 38.1 & 100.0 \\
\hline Cumulative Frequency & 21 & & \\
\hline \multicolumn{4}{|l|}{ Number of employees } \\
\hline $1-50$ & 4 & 19.0 & 19.0 \\
\hline $51-200$ & 7 & 33.3 & 52.3 \\
\hline $201-300$ & 3 & 14.3 & 66.7 \\
\hline $401-500$ & 5 & 23.8 & 90.4 \\
\hline More than 501 & 2 & 9.5 & 100.0 \\
\hline Cumulative Frequency & 21 & & \\
\hline \multicolumn{4}{|l|}{ Years of operating } \\
\hline $1-5$ & 9 & 42.9 & 42.9 \\
\hline $6-15$ & 7 & 33.3 & 76.2 \\
\hline $16-20$ & 3 & 14.3 & 90.4 \\
\hline More than 21 & 2 & 9.5 & 100.0 \\
\hline Cumulative Frequency & 21 & & \\
\hline \multicolumn{4}{|l|}{ Additional plants per enterprise } \\
\hline $1-2$ & 3 & 14.3 & 42.9 \\
\hline $3-4$ & 2 & 9.5 & 71.4 \\
\hline $5-9$ & 2 & 9.5 & 100.0 \\
\hline Cumulative Frequency & 7 & & \\
\hline
\end{tabular}

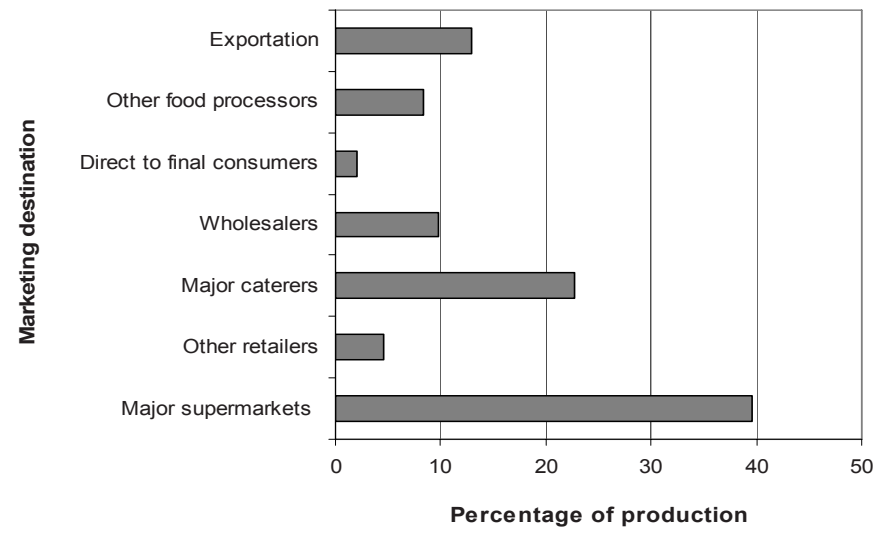

Fig. 1: Percentage of Mexican poultry meat production and main marketing destination of the 21 TIF enterprises surveyed. 
Major caterers received approximately $22 \%$ of the poultry meat production and a large group of enterprises formed part of their customer list. In contrast, eleven enterprises exported $12.9 \%$ of the poultry meat production. As it is indicated (Henson and Wilson, 2002), this low exporting percentage is because enterprises must be able to comply with food safety requirements and to demonstrate that compliance has been achieved. Thus, this goal to implement effective food safety control is of vital importance to food exports from developing countries.

There were six reported export destinations. They are shown in Fig. 2. The firms mentioned that the major part of their production, almost $50.0 \%$, was shipped to Japan; however, only three firms shared with the trading relationship. Northcutt and Scott (2003) indicated that it was possible because these firms operated HACCP system with other control systems to improve product safety.

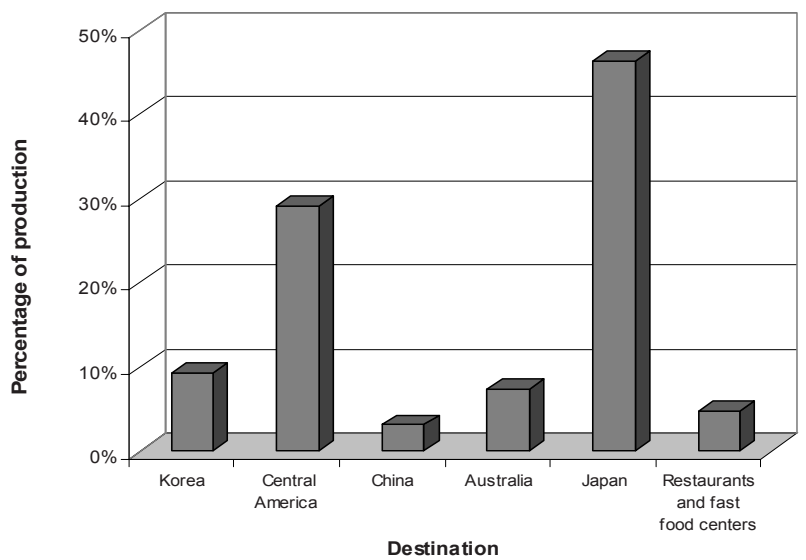

Fig. 2: Exporting poultry meat production and country destination of TIF enterprises surveyed.

Central America is the second destination for poultry meat (29.1\%), with lower quality standards and requirements. Each of the other four destinations acquires less than $10 \%$ of the production, three of them are of foreign origin and only one firm reported domestic trade relationship (4.8\%) with specific high pricing destination as restaurants and fast food centers. It is necessary to operate HACCP and other hygienic practices along production chain since they facilitate the exportation to most industrialized countries where food safety requirements should be warranted (Henson et al., 2000).

\subsection{HACCP Status}

In reference to the status of HACCP adoption, in total, $38.1 \%$ of respondents had fully operational HACCP systems in place (Table 2). Of 
these, all firms claimed to have full documentation. Furthermore, only $37.5 \%$ of them declared that the HACCP system operating in their plants has been verified and audited by a third party and only one firm had operational ISO 9000. Consequently, it can be possible that most of respondents were on path of having fully operational HACCP systems. Besides, they may perceive benefits from HACCP by dealing with other firms with adopted and having HACCP as well as a common business practice between them. Over $50.0 \%$ had a fully operational system for at least 24 months, whilst the remaining $50.0 \%$ had a fully operational HACCP system for 12 months.

Table 2. HACCP status of meat poultry plants responding survey

\begin{tabular}{lccc}
\hline \multicolumn{1}{c}{ HACCP Status } & Frequency & Percentage & Cumulative percentage \\
\hline Fully operational & 8 & 38.1 & 38.1 \\
Being implemented & 3 & 14.3 & 52.4 \\
Planned but not implemented & 7 & 33.3 & 85.7 \\
No plans to implement & 3 & 14.3 & 100.0 \\
Cumulative Frequency & 21 & & \\
\hline
\end{tabular}

The second group of firms involved those with the status still of being operating HACCP (14.3\%) and one of them had fully operational ISO 9000. They were interested to be included in the list of regular domestic and foreign suppliers.

On the other side, $33.3 \%$ were on the path to begin the adoption of the HACCP system. They were mainly pulling off with structural changes of plants, optimizing staff training and investing in new equipment.

Finally, the last group of three firms pointed out that they had no interest to adopt HACCP. The main reasons for this decision were high costs to implement/operate, lack of knowledge of HACCP and the fact that in Mexico is not a legal requirement in domestic market. However, capacity for food safety remains far below international standards (Henson et al., 2000; Henson and Wilson, 2002) and food safety requirements are considered as barrier.

\subsection{Motivating factors for HACCP implementation}

Previous studies have registered motivations for implementing HACCP systems on firms (Vanguard Consulting, 1993; Deodhar, 2003; Fouayzi et al., 2005). Respondents were presented a list of reasons to adopt HACCP. They were asked to rank them by the importance of 14 reasons on a scale of 0-7. Results of the average responses of TIF poultry processing sector are described in Table 3. 
Among these poultry processing firms, the attraction of new customers for their products had the highest score, following by improving of product quality. This probably reflects the fact that domestic market is the most important destination for their products. Moreover, the lowest rated was the reason of being recommended HACCP implementation by trade organizations. This could be an indication that trade organizations were either not having close communication, or HACCP was not yet of importance for domestic market.

Table 3. Average scores for HACCP adoption reasons by TIF poultry meat processing enterprises (scale 0 to 7 )*

\begin{tabular}{lcc}
\hline \multicolumn{1}{c}{ Concept } & Mean Score* & Std Dev \\
\hline Attract new customers for products & 1.2 & 0.5 \\
Improve product quality & 1.9 & 2.0 \\
Reduce need for quality audits by customers & 2.2 & 2.1 \\
Improve control of your production process & 2.2 & 2.0 \\
Access new overseas markets & 2.3 & 2.4 \\
Improve efficiency/profitability of the plant & 2.3 & 1.7 \\
Needed for plant to be third party accredited & 2.4 & 2.3 \\
Hold onto existing customers for products & 2.5 & 1.7 \\
Generally regarded as good practice & 2.8 & 1.8 \\
To meet the needs of major customers & 2.9 & 2.4 \\
To meet legal requirements & 3.1 & 2.3 \\
Reduce customer complaints & 4.2 & 2.6 \\
Reduce product wastage & 4.9 & 2.2 \\
Recommended by trade organization & 5.7 & 1.9 \\
\hline
\end{tabular}

*Where $1=$ very important and $7=$ unimportant.

\subsection{Costs and benefits}

Respondents were asked to rank the individual costs of implementing and operating, as well as the benefits involved in adopting HACCP process, which previous studies have suggested they result from implementation and/or operation of quality control assurance systems (Vanguard Consulting, 1993). In order to describe the importance of set-up cost in HACCP implementation (Deodhar, 2003), identified a number of one-time fixed cost concepts as "major cost" or "minor cost" by the enterprises (Table 4).

An important fact is that more than $85.5 \%$ of enterprises considered "external consultants" as the major cost to adopt HACCP. It was registered as a major cost by $37.5 \%$ of slaughter and packing, and none nuggets in poultry processing plants. On the contrary, $50.0 \%$ of them considered "managerial changes to the plant" as a minor cost of adopting HACCP system, and $25.0 \%$ of slaughter and packing plants recorded as minor cost as well. These results agreed with those presented by Deodhar (2003) in the Indian Food Processing Industry. The difference between the responses by 
processes for adopting costs considered "major" or "minor" was statistically significant $(\mathrm{P}<0.0001)$.

Table 4. Sector-specific importance of HACCP Set-up cost of adopting and operation ( $\mathrm{I}=$ Major Cost; $\mathrm{II}=$ Minor Cost $)$.

\begin{tabular}{|c|c|c|c|c|c|c|c|c|c|c|c|c|}
\hline & \multicolumn{12}{|c|}{ Set-up Costs of Adopting } \\
\hline & \multicolumn{2}{|c|}{ Cold cuts } & \multicolumn{2}{|c|}{ Nuggets } & \multicolumn{2}{|c|}{$\begin{array}{c}\text { Pasteurized } \\
\text { liquid and } \\
\text { dehydrated } \\
\text { eggs }\end{array}$} & \multicolumn{2}{|c|}{$\begin{array}{l}\text { Prepared } \\
\text { meals }\end{array}$} & \multicolumn{2}{|c|}{$\begin{array}{c}\text { Slaughter } \\
\text { and } \\
\text { packing }\end{array}$} & \multicolumn{2}{|c|}{ Total } \\
\hline & $\mathrm{I}$ & II & $\mathrm{I}$ & II & I & II & I & II & $\mathrm{I}$ & II & I & II \\
\hline External consultants & 1 & 0 & 0 & 1 & 2 & 0 & 1 & 0 & 3 & 0 & 7 & 1 \\
\hline Investment in new equipment & 1 & 0 & 1 & 0 & 0 & 1 & 1 & 0 & 3 & 0 & 6 & 1 \\
\hline Staff training & 1 & 0 & 1 & 0 & 2 & 0 & 0 & 0 & 2 & 1 & 6 & 1 \\
\hline Managerial changes to the plant & 0 & 1 & 0 & 0 & 0 & 1 & 1 & 0 & 0 & 2 & 1 & 4 \\
\hline Structural changes to plant & 0 & 1 & 1 & 0 & 0 & 1 & 1 & 0 & 0 & 1 & 2 & 3 \\
\hline $\begin{array}{l}\text { Staff time in documenting } \\
\text { system }\end{array}$ & 1 & 0 & 0 & 0 & 2 & 0 & 0 & 0 & 3 & 0 & 6 & 0 \\
\hline
\end{tabular}

In reference to four operating costs involved in HACCP implementation, enterprises agreed that all of them were considered of major importance to their cost estimation. However, costs generated by record keeping activities and staff training programs were considered of major relevance into their formal estimating plans. Then, all costs involved for product testing and payments to managerial and/or supervisory time were followed in significance for these enterprises.

Cost item with all activities involved in record keeping was considered a critical cost by slaughter and packing poultry processing plants in Mexico, this is also reported by small-scale food processing industry (SSI) in India and in United Kingdom (UK) in the dairy processing plants (Deodhar, 2003; Henson et al., 1999). Finally, it is of relevance that there were not minor costs registered by any of these TIF poultry processing enterprises. However, the consistency of these results is directly correlated by the ability of firms to identify these two types of costs. Given that simultaneously many respondents may have other changes on plants, so it could be difficult for them to identify the two types of costs clearly.

Regarding main benefits of implementing and operating the HACCP system in the Mexican poultry processing sector, those concerning product and customer were of key significance for enterprises, Fig. 3. Reduction of microbial counts and the possibility of increased price for products were the major benefits pointed out. The following benefits in order of importance were those involved in having higher ability to retain existing customer and to attract new customers, as well as the fact of increasing shelf life of products. In the opposite, benefits of minor importance for poultry meat 
processing industries were related with reduction of product wastage and the possibility of increasing the supervisory/managerial staff's motivation.

The quantitative impact of HACCP into poultry industrial processes was difficult to assess because it was complicated to isolate the impact of HACCP from other changes that were carried out simultaneously in their plants. Therefore, the higher than expected levels of certain benefits, such as the ability to attract new customers and retain existing clients, should be regarded with caution. In addition, there is evidence that a high proportion of the meat-processing enterprises interviewed do not formally monitor costs derived from insuring food safety and quality (Maldonado et al., 2005).

$\square$ Major benefit $\square$ Minor benefit

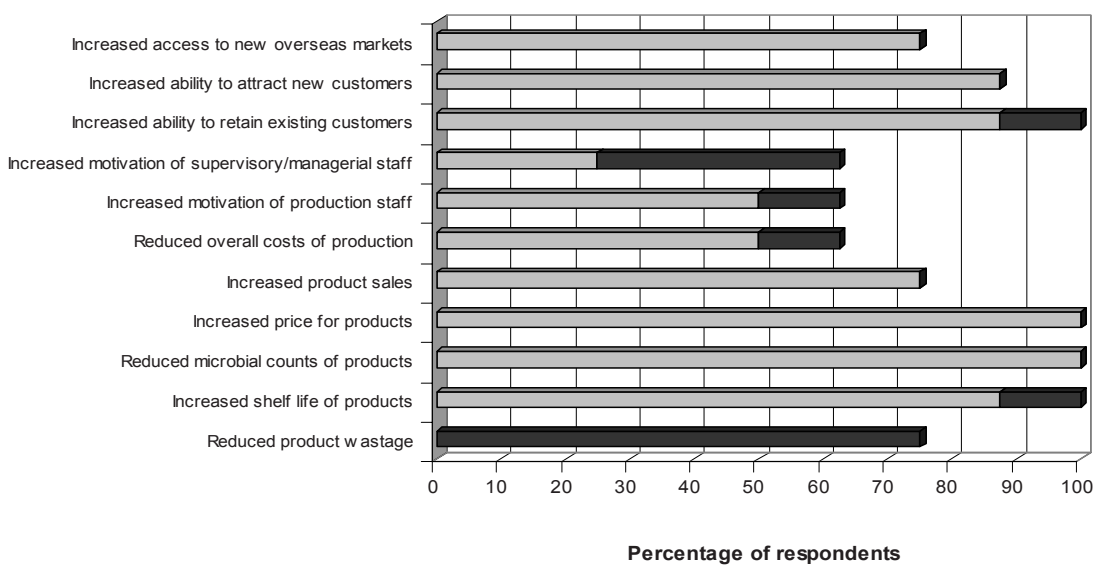

Fig. 3: Specific-sector of major and minor importance of benefits of implementing/operating $\mathrm{HACCP}$ in the poultry meat processing industry.

\section{CONCLUSIONS}

It is already affirmed that HACCP system is based on scientific, systematic and rational approach. It also identifies, assesses and controls hazards not only from production to distribution, but also on transportation and preparation of food. This is integration into the design of the food process that is applied to the whole food chain. For that reason, this study provides one of the first assessments of costs and benefits associated with the implementation of HACCP in the Mexican poultry processing sector. For instance, those costs of adopting, as consulting and operating services involved with record keeping and staff training are of major concern for the enterprises surveyed.

Some of the major benefits of HACCP are primarily intended to consumers, industry and governments as well. Specific domestic markets has 
been the major reason of the implementation of HACCP system in the Mexican poultry processing sector, joined with requests of international trade. Therefore, HACCP offers a good chance of attracting new customers for enterprises' higher quality products. It seems that, the trend towards higher food safety standards will be a continuous demand to both developing and developed countries, thus HACCP system for poultry meat industries ensures food safety production.

\section{ACKNOWLEDGMENTS}

We acknowledge the assistance of Managerial Directors and the Official Veterinarians of the TIF enterprises.

\section{REFERENCES}

A. Engler, H. Guy, D. H. Iglesias, A. A. Florindo, G. Gutiérrez, E. Salay, Actor-organization for QAS along agro-supply-chains: the case of mycotoxins reduction in Sourthern Cone Grains. 92 Seminar EAAE, Göttingen, Germany. 2005.

A. S. Martin, W. D. Anderson. HACCP Adoption in the U.S. Food Industry. In: The Economics of HACCP: Costs and Benefits. Laurian J. Unnevehr (Eds.) Eagen Press. Minnesota. USA. 15-28. 1999.

C. Calatore, A. J. Caswell. The Cost of HACCP Implementation in the Seafood Industry: A Case Study of Breaded Fish. In: The Economics of HACCP: Costs and Benefits. Laurian J. Unnevehr (Eds.) Eagen Press. Minnesota. USA. 1999, 45-68.

E. Dohlman. Mycotoxin Hazards and Regulations: Impacts on Food and Animal Feed Crop Trade. In: Buzby Ed. 2003. International Trade and Food Safety: Economic Theory and Case Studies, Agricultural Economic Report 828. USDA, ARS. 2003.

E. Salay, J.A. Caswell. Developments in Brazilian Food Safety Policy, International Food and Agribusiness Management Review, 1998, 1: 167-177.

H. Fouayzi, J. A. Caswell, N. H. Hooker. Motivations of Fresh-Cut Produce Firms to Implement Quality Management Systems. Review of Agricultural Economics, 2005, 28: $132-146$.

J. K. Northcutt, M. R. Scott. General Guidelines for Implementation of HACCP. The University of Georgia, Cooperative Extension Service College of Agricultural and Environmental Sciences Department of Poultry Science. Bulletin 1155. 2003.

K. Segerson. Mandatory Versus Voluntary Approaches to Food Safety. Agribusiness, 1999, 15: 53-70.

L. J. Unnevehr, H. J. Jensen,. Industry Compliance Costs: What Would They Look Like in a Risk-Based Integrated Food System?. Working Paper 01-WP 278. Center for Agricultural and Rural Development. Iowa State University. Ames, IA, USA. 2001.

L. J. Unnevehr, H. J. Jensen. The Economic Implications of Using HACCP as a Food Safety Regulatory Standard. Working Paper 99-WP 228. Center for Agricultural and Rural Development Iowa State University. Ames, IA, USA. 1998. 
S. E. Maldonado, S. J. Henson, J. A. Caswell, L. A. Leos, P. A. Martinez, G. Arand, J. A. Cadena. Cost-Benefit Analysis of HACCP Implementation in the Mexican Meat Industry. Food Control, 2005, 16: 375-381.

S. J. Henson, G. Holt, J. Northen. Cost and benefits of implementing HACCP in the UK dairy processing sector. Food Control, 1999, (10): 99-106.

S. J. Henson, J. Wilson. Understanding the Nature of Sanitary and Phytosanitary Capacity. World Bank. Washington, D. C. 2002.

S. J. Henson, J.A. Caswell. Food Safety Regulation: An Overview of Contemporary Trends. Food Policy, 1999, 24: 589-603.

S. J. Henson, R. Loader, A. Swinbank, M. Bedahl, N. Lux Impact of Sanitary and Phytosanitary Measures on Developing Countries. University of Reading. Centre for Food Economics Research. Reading, UK. 2000.

S. Y. Deodhar. Motivation for and cost of HACCP in Indian food processing Industry. Indian Journal of Economics and Business, 2003, 2:193-208.

SAS. SAS/STAT User's Guide (Release 8.2). Cary, NC, USA: SAS Inst. Inc. 2001.

Vanguard Consulting. BS 5750 Implementation and Value Added. Vanguard Consulting Ltd. Buckingham. 1993. 